\title{
Jak hodnotili čeští patnáctiletí žáci základních škol a studenti víceletých gymnázií environmentální problémy
}

\author{
Linda Schmutzerová, Martin Bílek \\ Envigogika 2010/V/2- Recenzované články/ Reviewed Papers \\ Publikováno/Published 30. 09. 2010 \\ DOI: http://dx.doi.org/10.14712/18023061.54
}

\begin{abstract}
Abstrakt:
V článku se zabýváme analýzou postojů českých patnáctiletých žáků základní školy a studentů gymnázia $v$ oblasti tvorby a ochrany životního prostředí a environmentálních problémů. Jde o analýzu části "Já a výzvy životního prostředî" mezinárodního projektu ROSE (Relevance of Science Education), kterého se zúčastnilo od roku 2005 v Ceské republice více než 2000 respondentů. Z analýz vyplývá, že čeští patnáctiletí žáci základních škol a studenti gymnázií vnímají ohrožování životního prostředí jako věc, která se jich bezprostředně týká a že $\mathrm{k}$ nápravě mohou přispět i oni sami. Statisticky významné rozdíly byly zaznamenány $v$ největším rozsahu $v$ názorech dívek a chlapců, menší rozdíly byly detekovány $v$ názorech respondentů ve prospěch studentů gymnázia a nebyly zaznamenány rozdíly podle velikosti bydliště žáků a studentů.
\end{abstract}

\section{Klíčová slova:}

Postoje žáků k environmentálním problémům; Projekt ROSE; Názory na ochranu a tvorbu životního prostředí, environmentální výchova na ZŠ a gymnáziu

\begin{abstract}
:
The attitudes of 15-year-old Czech learners and students of primary schools and grammar schools in the environmental area are presented in this article. The results were obtained from the international project ROSE (Relevance of Science Education) - part of "Me and Environmental Challenges" in which more than 2000 respondents from the Czech Republic took part. By analysis of Likert-scales it was demonstrated that Czech 15-year-old pupils view threats to the environment as an issue of immediate concern to them and to which they can contribute to making an improvement. Statistically significant differences were registered mostly in the opinions of boys and girls, smaller differences were detected in the opinions of grammar school studentsand no differences were recorded in relation to the residential size.
\end{abstract}

\section{Key words:}

Pupil's attitudes to environmental problems; Project ROSE; Opinions to environment conservation, Environmental education on primary and secondary school levels 


\section{Úvod}

Málokdy hledáme ve školním prostředí souvislosti otázek „co vyučovat a co se mají žáci naučit" s otázkou "co se žáci učit chtějí". Hledání těchto vazeb a zejména odpovědí souvisejících se zájmy žáků o předmět výuky by se mohlo stát klíčem k analýze jejich současného, ne príliš pozitivního vztahu k přírodovědnému vyučování, k pochopení často velmi nízké motivace $\mathrm{k}$ učení se přírodovědným předmětům. Odpovědi by navíc mohly pomoci do jisté míry pochopit někdy i výrazné rozdíly ve znalostech žáků z různých regionů, rozdíly $v$ zájmech dívek a chlapců apod. Takové problémy v plné míře odrážejí i diskuse výsledků mezinárodních srovnávacích výzkumů TIMSS a PISA. Z poněkud jiného pohledu než tyto dva známé komparativní projekty se zabývá zkoumáním postojů patnáctiletých žáků k přírodě, přirodním vědám, technologii a prírodovědné výuce mezinárodní projekt ROSE (Schreiner, Sjøberg, 2004; Sjøberg, 2002), jehož část zaměřená na environmentální souvislosti se stala předmětem tohoto sdělení. $V$ naší analýze se snažíme odpovědět na otázku, jaké názory mají na oblast environmentálních problémů souvisejících s přírodovědnou a technickou výukou patnáctiletí žáci českých základních škol a gymnázií.

Zkoumání postojů k environmentální problematice bylo cílem již řady studií. V centru našeho zájmu stoji např. výstupy speciálně tematicky zaměřené konference o environmentálních aspektech výuky chemie konané v Brně v roce 2007 (Cídlová, Šibor, 2007) či práce řady autorů, zabývajících se postoji jedince k př́rodě (např. Krajhanzl, 2007) environmentální senzitivitou (např. Franěk, nedat.) nebo obecněji problematikou environmentální výchovy (např. Činčera, 2007). Zajímavé a podstatné pro kontext interpretace názorů na environmentální problémy jsou i nejnovější poznatky z nově formované vědecké subdisciplíny nazývané "ekopsychologie" (conservation psychology) (Franěk, nedat.)

\section{Mezinárodní projekt ROSE}

Pro prezentaci názorů a postojů žáků k tvorbě a ochraně životního prostředí jsme v tomto sdělení využili analýzu části dat z mezinárodního srovnávacího projektu ROSE (Schreiner, Sjøberg, 2004), jehož hlavním cílem je zjištování názorů a vztahů žáků $\mathrm{k}$ prírodovědným předmětưm a technice $v$ mnoha zemích celého světa. Environmentální problematika, které se budeme $v$ našich analýzách věnovat, je také významnou součástí tohoto šetření a její výsledky z českého prostředí ještě nebyly u nás publikovány.

Projekt ROSE vznikl z iniciativy skupiny pracovníků katedry učitelství a rozvoje školství Univerzity v Oslu prof. Dr. S. Sjøberga a jeho doktorandky K. Schreinerové. Navázal na předchozí výzkumy uvedeného pracoviště v oblasti všeobecného přírodovědného vzdělávání, především na mezinárodní komparativní projekty SAS a GRASSMATE. Projekt SAS (Science and Scientist, viz Sjøberg, 2002) zkoumal zvláštnosti $v$ zájmech a $v$ prístupu třináctiletých dětí $\mathrm{k}$ přírodním vědám a $\mathrm{k}$ vědcưm, kteří se této oblasti věnují; spolupracovalo na něm třicet odborníků z 21 zemí třech kontinentů. Pod zkratkou GRASSMATE (Graduate Program in Science, Mathematics and Technology Education) se skrývá společný norsko-subsaharský projekt výzkumné spolupráce v oblasti přírodovědného vzdělávání (zapojeno bylo na dvacet studentů doktorských Ph.D. studijních programů) (Schreiner, Sjøberg, 2004).

Start projektu ROSE Ize datovat už na přelom let 2001 - 2002, kdy byl vytvořen mezinárodní dvanáctičlenný poradní tým, jehož úkolem bylo připravit dotazník pro patnáctileté žáky, který by umožňoval detekovat globální ale především lokální „relevanci" přírodovědného a technologického vzdělávání pro samotné žáky. Po řadě pilotních projektů byla finální podoba dotazníku dokončena v konci roku 2002 a v roce 2003 začal sběr empirických dat v jednotlivých participujících zemích. V konci roku 2004 projevilo zájem 
o provedení šetření více než 40 zemí všech obydlených kontinentů a na počátku roku 2005 byla $\mathrm{k}$ dispozici data $\mathrm{z}$ téměř třiceti zemí. Tehdy se do projektu zapojila i Česká republika (Bílek, 2005).

Významnost, důležitost, závažnost (relevance) přírodních věd a technologie (S\&T) a jejich výuky pro patnáctileté žáky, na níž je projekt ROSE zaměřen, Ize lapidárně vyjádřit ve třech základních tezích:

1. respektování kulturních odlišností a specifik v zájmech dívek a chlapců týkajících se S\&T a jejich výuky,

2. podpora osobního a sociálního významu S\&T,

3. posilování demokratického smýšlení a občanských principů u žáků a studentů i v oblasti S\&T.

Tyto teze podporují vyvracení mýtů o unifikovaném či univerzálním všeobecném př́rodovědném vzdělávání pro primární a nižší sekundární stupeň školských systémů, o ignorování lokálních specifik, o malé vazbě etických a afektivních prvků na př́rodovědné kurikulum apod.

Dotazník ROSE, který obsahuje celkem 266 položek, je rozdělen do jedenácti následujících okruhů:

1. Úvodní část (číslo dotazníku, identifikace pohlaví, věku a země respondenta, až čtyři další "národní" položky);

2. Co se chci učit (Byla by pro Tvé studium zajímavá následující témata?), 48 témat s výběrem polohy souhlasu na čtyřstupňové Likertově škále (nezajímavé - zajímavé);

3. Moje budoucí povolání (Jak významná jsou pro Tvé možné budoucí zaměstnání nebo povolání následující vyjádření?), 26 vyjádření s výběrem polohy souhlasu na čtyřstupňové Likertově škále (nevýznamné - významné);

4. Co bych se chtěl učit (Nakolik jsou pro Tvé učení zajímavá následující témata?), 18 témat $\mathrm{s}$ výběrem polohy souhlasu na čtyřstupňové Likertově škále (nezajímavé - zajímavé);

5. Já a výzvy životního prostředí (Do jaké míry souhlasíš s následujícími prohlášeními o problémech s životním prostředím (o environmentálních problémech) např. znečištování ovzduší a vody, vyčerpatelnost zdrojů, globální změny podnebí atd.? 18 prohlášení s výběrem polohy souhlasu na čtyřstupňové Likertově škále (nesouhlasím - souhlasím);

6. Co bych se chtěl učit (Nakolik jsou pro Tvé učení zajímavá následující témata?), 42 témat $s$ výběrem polohy souhlasu na čtyřstupňové Likertově škále (nezajímavé - zajímavé);

7. Mé hodiny prírodovědných předmětů (Do jaké míry souhlasíš s následujícími tvrzeními o prírodních vědách (př́rodověda nebo fyzika, chemie, biologie, zeměpis), které jsi měl ve škole?), 16 tvrzení s výběrem polohy souhlasu na čtyřstupňové Likertově škále (nesouhlasím - souhlasím);

8. Moje názory na vědu a technologii (Nakolik souhlasíš s následujícími tvrzeními?), 16 tvrzení $\mathrm{s}$ výběrem polohy souhlasu na čtyřstupňové Likertově škále (nesouhlasím - souhlasím); 
9. Moje mimoškolní zkušenosti (Jak často jsi to dělal mimo školní vyučování?), 61 činností s výběrem polohy souhlasu na čtyřstupňové Likertově škále (nikdy - často);

10. Já jako vědec (Představ si, že jsi už dospělý a pracuješ jako vědec. Máš volnost $v$ tom, co chceš zkoumat tak, aby to bylo důležité a zajímavé. Napiš pár vět o tom, co bys chtěl dělat jako vědec a proč. Chtěl bych... Protože... ), doplnění odpovědi;

11. Kolik asi knih máte doma?, výběr ze sedmi položek (od „žádné" až po více než 500).

V České republice byla navázána spolupráce s organizátory projektu ROSE na 11 . celosvětovém sympoziu IOSTE $v$ polském Lublinu $v$ červenci 2004. Na podzim téhož roku byla připravena česká mutace dotazníku a za pomoci obětavých spolupracovníků z jednotlivých krajů České republiky bylo provedeno na přelomu let $2004-2005$ empirické šetření. Dotazníky byly zadávány $\vee 9$. ročnících $Z$ š a $v$ kvartách osmiletých gymnázií. V každém kraji byly osloveny ZŠ a gymnázium z obce do 10 tis. obyvatel, ZŠ a gymnázium z obce od 10 tis. do 50 tis. obyvatel a ZŠ a gymnázium z obce nad 50 tis. obyvatel. $V$ každé škole byla snaha zadat dotazník v jedné třídě s cca 25 žáky (vstupní podmínka projektu ROSE byla minimálně 5 tř́́d s 25 žáky z 5 škol, tj. minimálně 625 respondentů). Na obr. 1 jsou uvedeny počty respondentů, kteř́ byli zařazeni do statistického zpracování z jednotlivých krajů. Kromě Pardubického kraje tak byly vyplněné dotazníky získány v každém kraji ze všech 6 oslovených škol (ze tř́ Zš a ze tří gymnázií podle výše uvedených parametrů). Výběr školy závisel na možnostech a volbě krajského spolupracovníka našeho projektu, jednalo se tedy o príležitostný výběr s podmínkou dodržení typu školy a velikosti sídliště. Celkem bylo $v$ České republice do výzkumu zařazeno 2005 respondentů, z toho bylo 1097 dívek a 908 chlapců, 1024 žáků ZŠ a 981 žáků gymnázií a průměrný věk respondentů činil 14,56 roku. 631 žáků navštěvovalo školu $\vee$ obci do 10 tis. obyvatel, $606 \mathrm{v}$ obci od 10 do 50 tis. a 768 v obci nad 50 tis. obyvatel.

Další zjištóvání názorů zaměřené na stabilitu postojů žáků proběhlo v letech 2008 a 2009 ve společném šetření organizovaném $v$ Lotyšsku, $v$ Polsku a $v$ České republice a prokázalo poměrně významnou stabilitu detekovaných postojů a zájmů respondentů (Gedrovics et al, 2008). 


\section{Obr. 1 Počty respondentů projektu ROSE v jednotlivých krajích České republiky}

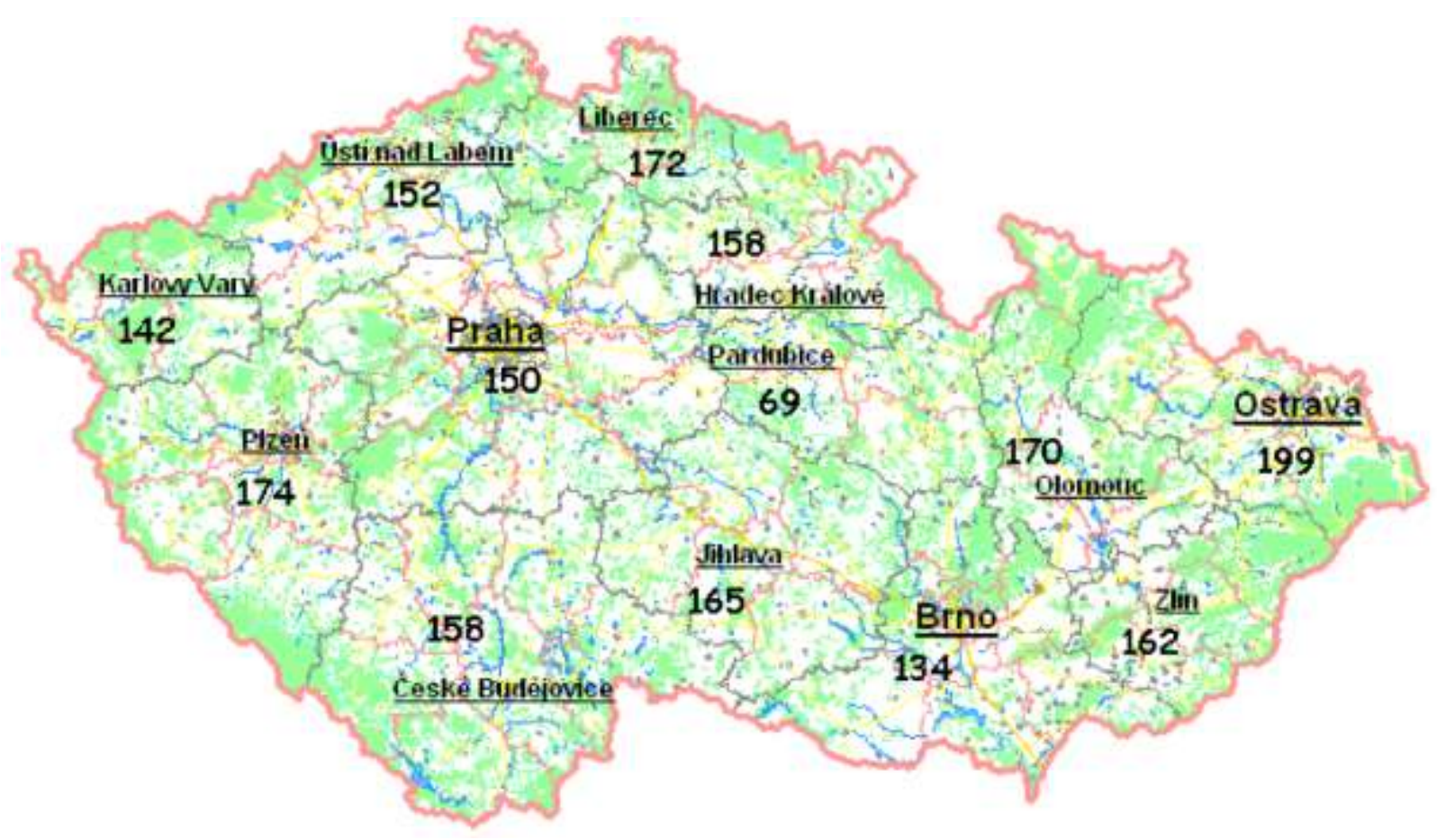

\section{Analýza vztahů a postojů žáků Zš a gymnázií v České republice k tvorbě a ochraně životního prostředí}

$\checkmark$ tomto sdělení se chceme podrobně zaměřit na část dotazníku ROSE zabývající se tvorbou a ochranou životního prostředí tj. část označenou "Já a výzvy životního prostředí.". Tato část projektu ROSE byla iniciována předpokladem, že environmentálně senzitivní lidé musejí (Schreiner, Sjøberg, 2004):

- být motivováni udělat něco pro řešení environmentálních problémů,

- mít zájem o budoucnost a její vizi,

- mít pocit, že sami mohou budoucí vývoj ovlivnit,

- mít zájem a angažovat se pro své životní prostředí,

- myslet na důležitost ochrany životního prostředí pro společnost.

$\mathrm{K}$ tomu musejí mít samozřejmě i dostatečné znalosti z této oblasti, znalosti pojmů dotýkajících se zdravého životního stylu, technických řešení, politických rozhodnutí apod.

Dotazník ROSE $v$ této části obsahuje 18 položek/tvrzení (viz př́loha 1), které autoři dotazníku modifikovali na základě výsledků řady empirických studií provedených $\checkmark$ posledních dvaceti letech (Schreiner, Sjøberg, 2004). Zajímal je zejména vliv budování tzv. př́rodovědné a technické gramotnosti (S\&T) na názory respondentů v environmentální oblasti a na jejich hodnocení možností, které věda a technologie k rešení nabízí nebo naopak řešení znesnadňuje. 
Analýzu výsledků dosažených $v$ České republice jsme rozdělili na několik částí. Zjištovali jsme postoje a názory na tvorbu a ochranu životního prostředí všech respondentů (část I), dále rozdíly $v$ odpovědích dívek a chlapců (část II), rozdíly v názorech žáků základních škol a gymnázií (část III) a také rozdíly v názorech žáků žijících na vesnicích a v malých městech (sídla do 10 tisíc obyvatel) a ve větších městech (sídla nad 10 tisíc obyvatel) (část IV).

\section{Názory a postoje českých patnáctiletých žáků a studentů na ochranu a tvorbu} životního prostředí - analýza celkových výsledků

Z odpovědí žáků a studentů je patrné, že vnímají ohrožování životního prostředí jako fenomén, který se jich bezprostředně týká, a budoucnost světa vidí spiše optimisticky. Za pesimisty bylo možné označit pouze $13 \%$ dotazovaných respondentů. Celkově Ize zaznamenat názory, že environmentální problémy nejsou zveličovány. Na druhou stranu se ale žáci domnívají, že věda ani technika nejsou schopny vyřešit všechny environmentální problémy. Usuzují také, že k vyřešení environmentálních problémů je potřeba změnit svůj životní styl. Je potěšitelné, že na 50 \% z nich se domnívá, že mưže sám za sebe významně přispět k ochraně životního prostředí, ale pouze menšinová část respondentů by byla ochotna pro vyřešení environmentálních problémů obětovat mnohé své požitky. Více než tři čtvrtiny dotazovaných respondentů se domnívají, že lidé by se měli více starat o ochranu životního prostředí, ale $42 \%$ nesouhlasí s tím, že by skoro veškerá lidská činnost byla pro životní prostředí škodlivá. To si myslí jen 8 \% patnáctiletých žáků českých základních škol a víceletých gymnázií.

Názory a postoje českých patnáctiletých žáků a studentů na ochranu a tvorbu životního prostředí - analýza rozdílu v postojích dívek a chlapců

$\checkmark$ druhé části našich analýz jsme se zaměřili na rozdíly $v$ názorech a postojích k ochraně životního prostředí u dívek a chlapců. Odpovědi dívek a chlapců, vyjadřované stupněm souhlasu s příslušným tvrzením na čtyřstupňové Likertově škále $v$ jednotlivých 18 položkách, byly zpracovány pomocí "Chí kvadrát testu”, který byl preferován před jinými metodami statistického zpracování dat, např. před "t-testem". Ten je na rozdíl od naší situace vhodnější spiš̌e pro aplikace na jevy, při nichž známe určitou konstantní hodnotu, kterou můžeme považovat za průměr základního souboru a ten porovnáváme se zjištěným stavem.

Byly formulovány následující statistické hypotézy:

Hypotéza $\mathrm{H}_{0}$ : Neexistují rozdíly $v$ odpovědích dívek a chlapců.

$\mathrm{H}_{\mathrm{A}}$ : Existují rozdíly $v$ odpovědích dívek a chlapců.

Posouzení probíhalo na hladině významnosti $0,01 \mathrm{~s}$ kritickou hodnotou $=11,345$. Výsledky statistického zpracování jsou uvedeny v tabulce 1 (sloupec označený "Část II"). Z odpovědí dívek i chlapců a $z$ jejich statistického vyhodnocení je patrné, že statisticky významné rozdíly $\vee$ odpovědích dívek a chlapců existují. Obecně Ize konstatovat, že jak dívky, tak i chlapce problematika životního prostředí zajímá (60 \% dívek a $49 \%$ chlapců se domnívá, že se jich ohrožování životního prostředí nějakým způsobem dotýká). Mají pocit, že environmentální problémy nejsou zveličovány, jsou si vědomi toho, že je třeba pro ochranu životního prostředí a zajištění trvale udržitelného rozvoje něco dělat, ale nejsou př́liš ochotni tomu obětovat své požitky. $V$ tomto aspektu ale panuje u dívek i u chlapců shoda - pouze $37 \%$ dívek a $38 \%$ chlapců by bylo ochotno své požitky ve prospěch životního prostředí obětovat. Polovina dívek $\mathrm{i}$ chlapců jsou při pohledu do budoucnosti optimisté, přestože velká část $92 \%$ dívek a $86 \%$ chlapců zastává názor, že lidé by se měli více starat o ochranu životního prostředí. Je možné říci, že dívky vnímají potřebu ochrany životního prostředí pozitivněji než chlapci. Trochu překvapivý rozdíl je v pohledu dívek a chlapců na problematiku toho, zda zviŕata mají stejné právo na život jako lidé. Zatímco $82 \%$ dívek si myslí, že ano, tak u chlapcù je to pouze $51 \%$ respondentů. 
Názory a postoje českých patnáctiletých žáků a studentů na ochranu a tvorbu životního prostředí - analýza rozdílu v postojích žáků základních škol a studentů gymnázií

V třetí části našich analýz jsme se zaměřili na rozdíly $v$ názorech a postojích k ochraně životního prostředí u žáků a studentů základních škol (ZŠ) a gymnázií (Gy). Odpovědi žáků ZŠ a studentů Gy ve všech 18 položkách byly opět zpracovány pomocí "Chí kvadrát testu". Byly formulovány následující statistické hypotézy:

Hypotéza $\mathrm{H}_{0}$ : Neexistují rozdíly v odpovědích studentů Gy a ZŠ.

$\mathrm{H}_{\mathrm{A}}$ : Existují rozdíly v odpovědích studentů Gy a ZŠ.

Posouzení probíhalo také na hladině významnosti $0,01 \mathrm{~s}$ kritickou hodnotou $=11,345$ (výsledky zpracování jednotlivých položek ukazuje sloupec v tabulce 1 označený „Část III"). Z výsledků statistického šetření je patrné, že mezi studenty ZŠ a Gy existují statisticky významné rozdíly, ale nejsou tak významné jako u rozdílu pohlaví. Naprostá shoda je patrná v názoru studentů ZŠ a Gy k používání pokusných zvírat u experimentů, pokud by se tím dal zachránit lidský život. Výrazná většina žákư ZŠ (78 \%) i studentů Gy (78 \%) ale obecně s experimentováním na pokusných zvířatech nesouhlasí. Menší rozdíly v názorech ve prospěch pozitivnějšího postoje studentů gymnázia Ize zaznamenat např. u následujících názorů: 74 \% žákư ZŠ a 82 \% studentů Gy si myslí, že se jich ohrožování životního prostředí týká, 86 \% žákư ZŠ a $92 \%$ studentů Gy si myslí, že je třeba se více starat o ochranu životního prostředí a jen 67 \% žáků ZŠ na rozdíl od 80 \% studentů Gy se domnívá, že řešení environmentálních problémů není pouze záležitostí odborníků. Je možné říci, že studenti Gy si více uvědomují nutnost potřeby ochrany životního prostředí, což mưže být způsobeno i tím, že mají o této problematice více informací, které získávají během studia ve škole, at' už v rámci přírodovědných předmětů nebo vlastním studiem (internet, noviny, časopisy apod.), pravděpodobně i pobytem $v$ informačně bohatším prostředí.

Názory a postoje českých patnáctiletých žáků a studentů na ochranu a tvorbu životního prostředí - analýza rozdílu v názorech žáků a studentů pocházejících z vesnic a malých měst do 10 tis. obyvatel a měst nad 10 tis. obyvatel

Ve čtvrté části našich analýz jsme se zaměřili na rozdíly $v$ názorech a postojích k ochraně životního prostředí u žáků a studentů pocházejících z vesnic a malých měst (do 10 tis. obyvatel) a měst nad 10 tis. obyvatel. I tyto odpovědi respondentů byly ve všech 18 položkách zpracovány pomocí "Chí kvadrát testu”. Byly formulovány následující statistické hypotézy: Hypotéza $\mathrm{H}_{0}$ : Neexistují rozdíly $v$ odpovědích žákư a studentů pocházejících z vesnic a měst do 10 tis. obyvatel a měst nad 10 tis. obyvatel.

$\mathrm{H}_{\mathrm{A}}$ : Existují rozdíly $v$ odpovědích žáků a studentů pocházejících z vesnic a měst do 10 tis. obyvatel a měst nad 10 tis. obyvatel

Stejné bylo posouzení statistické významnosti rozdílů na hladině významnosti 0,01 s kritickou hodnotou = 11,345 (výsledky jsou v tabulce 1 ve sloupci "Č́st IV"). Z výsledků statistického šetření je patrné, že velikost místa, v němž respondent bydlí, $v$ podstatě nemá vliv na jeho postoje a názory. Jak respondenti z vesnic a malých měst (75\%) tak z větších měst (78 \%) mají pocit, že ohrožování životního prostředí se jich bezprostředně týká. Řešit environmentální problémy za cenu obětování svých požitků je ochotno $39 \%$ respondentů z vesnic a malých měst a $38 \%$ respondentů z větších měst. Žáci a studenti z vesnic a z malých měst ( $88 \%)$ i z větších sídlišt' ( $90 \%)$ se domnívají, že by se měli více starat o ochranu životního prostředí. Výrazným varováním je fakt, že více než třetině respondentů z obou skupin $(40 \%)$ se jeví budoucnost pohledem environmentálních problémů jako poměrně bezútěšná až beznadějná. 
Tab. 1 Výsledky jednotlivých částí statistické analýzy postojů

\begin{tabular}{|c|c|c|c|}
\hline \multirow[t]{2}{*}{ Číslo otázky } & Část II & Část III & Část IV \\
\hline & $x^{2}$ & $x^{2}$ & $x^{2}$ \\
\hline 1 & 39,85 & 26,14 & 4 \\
\hline 2 & 12,12 & 4,22 & 20,4 \\
\hline 3 & 25,83 & 7,04 & 1,686 \\
\hline 4 & 109,01 & 5,932 & 9,979 \\
\hline 5 & 11,478 & 6,99 & 2,895 \\
\hline 6 & 17,119 & 8,26 & 2,14 \\
\hline 7 & 24,59 & 4,49 & 1,453 \\
\hline 8 & 15,38 & 15,58 & 5,99 \\
\hline 9 & 7,64 & 13,74 & 1,811 \\
\hline 10 & 53,92 & 19,74 & 3,113 \\
\hline 11 & 73,95 & 4,975 & 5,224 \\
\hline 12 & 74,15 & 26,21 & 1,734 \\
\hline 13 & 38,20 & 53,5 & 2,643 \\
\hline 14 & 6,82 & 15,145 & 1,693 \\
\hline 15 & 74,77 & 10,13 & 4,175 \\
\hline 16 & 68,40 & 8,604 & 1,607 \\
\hline 17 & 22,62 & 24,272 & 3,729 \\
\hline 18 & 7,14 & 13,890 & 5,039 \\
\hline
\end{tabular}




\section{Závěr}

Provedené analýzy ukazují, že v České republice vnímají patnáctiletí žáci základních škol a studenti gymnázií ohrožování životního prostředí jako věc, která se jich bezprostředně týká a jejich názory se nijak výrazně neliší od respondentů v ostatních zemích účastnících se projektu ROSE (Schreiner, 2006; Gedrovics, 2005; Uitto et al, 2005). Vědí, že k vyřešení tohoto komplexu problémů můžou přispět i oni sami, a to zejména změnou svého životního stylu a svou budoucnost vnímají spíše optimisticky. Nepřeceňují přínos vědy a technologie k řešení environmentálních problémů, ale vidí spíše jejich užitek než stinné stránky. To plně koresponduje s mnohými výzkumy provedenými v západních zemích v konci osmdesátých a v devadesátých letech (např. Eckersley nebo Hicks a Holden v (Schreiner, Sjøberg, 2004)). Z našich výsledků je patrné, že existují statisticky významné rozdíly $v$ postojích a názorech patnáctiletých dívek a chlapců. Je možné konstatovat, že dívky vnímají potřebu ochrany životního prostředí pozitivněji než chlapci a v souladu s výzkumy Eckersleye (Schreiner, Sjøberg, 2004) a Schreinerové a Sjøberga (Schreiner et al, nedat.) jsou skeptičtější k př́nosu vědy a technologie $k$ řešení environmentálních problémů. Také studenti gymnázií si více uvědomují nutnost potřeby ochrany životního prostředí než žáci základních škol, což by měla být velká výzva pro inovaci vzdělávacích obsahů v této úrovní školského systému. Domníváme se, že současné kurikulární řešení tohoto problému prostřednictvím tzv. „prưřezového tématu" Environmentální výchova je sice slibným krokem nápravy, ale ne dostatečným. Jeho realizace integrací vytýčených témat v tradičních učebních předmětech nebývá dostatečná a na druhou stranu realizace samostatnými projekty ve formě projektových dnů nebo delších časových "projektových" celků nesplňuje svůj účel, který by měl být tzv. projektově efektivní. Jedná se často spíše o projekty učitelů, kdy žáci plní úkoly tak, jako při tradiční výuce, pouze výstupy a hodnocení mívají jinou, "pro žáky přijatelnější", formu. Z našeho pohledu se tak stále větší výzvou stává diskuse a realizace učitelské aprobace s tímto zaměřením tak, jak ji známe z některých jiných evropských zemí. K formulaci jejího obsahu mưžeme $v$ analyzovaném výzkumu nalézt velmi mnoho zajímavých podnětů.

Celkově Ize konstatovat, že statisticky významné rozdíly byly zaznamenány v největším rozsahu $v$ odpovědích dívek a chlapců, menší rozdíly byly detekovány v názorech studentů gymnázia a základní školy a nebyly zaznamenány téměř žádné rozdíly v názorech respondentů rozdělených podle velikosti jejich bydliště. Tady se projevují dle našeho názoru ne př́liš velké rozdíly života $v$ našem teritoriu mezi sídlišti menšími a většími než 10 tisíc obyvatel, na něž se naše analýza zaměřila. Pro navazující výzkumy by bylo asi zajímavější pokusit se o analýzu názorư žáků spíše z různých regionů např. v závislosti na "ratingu" kvality života apod.

Závěrem Ize konstatovat, že provedená analýza otvírá řadu otázek k inovaci přírodovědného a technického, a tak, jak jsme naznačili, i specificky environmentálního, vzdělávání na našich základních školách. Např. současné podhodnocení zejména technicky a technologicky orientované části kurikula, zastoupené ne př́liš obsahově i časově dotovanou vzdělávací oblastí "Člověk a svět práce", toho mưže být jednou z podstatných příčin. Ovšem takové vyučování nemůže být zaměřeno pouze praxeologicky, tedy na získávání technických a technologických dovedností, ale musí se orientovat i na oblast vědomostí o technice a technologiích ovlivňujících výrazným způsobem naše životní prostředí a zejména na hodnocení jejich pozitivního a negativního vlivu na trvale udržitelný rozvoj společnosti. Naše další výzkumy jsou tak orientovány nejen na zkoumání názorů žáků, ale i na vazby mezi získávanými vědomostmi a postoji, mezi schopností aplikace nabytých vědomostí a proměn postojů $k$ environmentálním problémům a jejich přírodovědným a technickým, $v$ našem případě zejména chemickým a chemickotechnologickým, souvislostem.

V př́loze 2 ještě uvádíme pro zajímavost vždy pět nejvíce pozitivně a nejvíce negativně hodnocených tvrzení a průměrnou hodnotu jejich hodnocení na čtyřstupňové 
Likertově škále, když hodnota 4 je maximem pozitivního a hodnota 1 maximem negativního postoje (střed $=2,5$ ).

\section{Poděkování:}

Autoři děkují prof. RNDr. PhDr. Zdeňku Půlpánovi, CSc. za pomoc při volbě metody statistického zpracování získaných dat a při interpretaci získaných výsledků.

\section{Literatura}

- BÍLEK, Martin. Why to Learn Science and Technology? Selected Results of the International ROSE Project. In MECHLOVÁ, Erika (ed.) Information and Communication Technology in Education - Proceedings. Ostrava: University of Ostrava, 2005, s. 11 - 14, ISBN 80-7368081-5.

- CÍDlOVÁ, Hana, ŠIBOR, Jiří (eds.) Příprava učitelů chemie na environmentální výchovu a výchovu k trvale udržitelnému rozvoji - Sborník př́spěvků z mezinárodní konference. Brno: Pedagogická fakulta Masarykovy univerzity, 2007, ISBN 978-80-210-4504-0.

- ČINČERA, Jan. Environmentální výchova: od cílů k prostředkům. Brno: Paido, 2007, ISBN 978-80-7315-147-8.

- $\quad$ FRANĚK, Marek. Psychosociální faktory ovlivňující úspěšnost environmentální výchovy. [online] [cit. 2010-09-01] Dostupné na WWW: http://www.volny.cz/evans01/sisyfos/ fr studie.rtf

- GEDROVIČS, Janis, BÍLEK, Martin, JANIUK, Ryszard Matej, MOJSA, Robert, MOZHEIKA, Daina, ŘÁDKOVÁ, Olga. Trendy v zájmech a postojích patnáctiletých žákứ $\mathrm{k}$ prírodním vědám. Acta Fac. Paed. Univ. Tyrnaviensis, Ser. D., Supplementum 2, Nr. 12, 2008, s. 13 17, ISBN 978-80-8082-182-1.

- GEDROVICS, Janis. The International Comparative Project ROSE and the Place of Chemistry in it. In Konferences Kimijas izglitiba skola- 2005 rakstu krajums. Riga: LU Akadeemiskais apgaads, 2005, p. 46 - 54, ISBN 9984-783-11-1.

- KRAJHANZL, Jan. Psychologické pojmosloví charakteristiky vztahu jedince $k$ prírodě. Praha: FF UK, 2007. [Anotace disertační práce].

- SCHREINER, Camilla, SJøBERG, Svein. Sowing the seeds of ROSE. Background, Rationale, Questionnaire Development and Data Collection for ROSE (The Relevance of Science Education) - a comparative study of students' views of science and science education. Acta Didactica, 4/2004, Oslo: Dept. of Teacher Education and School Development, University of Oslo, 2004, ISSN 1502-2013.

- $\quad$ SCHREINER, Camilla, SJøBERG, Svein. Optimists or Pessimists? How do young people relate to environmental challenges? [on-line] [cit. 2010-05-24] Dostupné na WWW: http://www.ils.uio.no/forskning/rose/

- SCHREINER, Camilla. Exploring a ROSE-garden Norwegian Youths Orientations toward Science - Seen as Signs of Late Modern Identities [Dissertation]. Oslo: Faculty of Education University of Oslo, 2006.

- SJøBERG, Svein. Science for the Children? Report from the Science and Scientist - project. Acta Didactica, 1/2002. Oslo : Dept. of Teacher Education and School Development, University of Oslo, 2002, ISSN 1502-2013.

- UITTO, Anna, JUUTI, Kalle, LAVONEN, Jarri, MEISALO, Veijo. Who is responsible for sustainable development? Attitudes to environmental challenges: A survey of Finnish $9^{\text {th }}$ grade comprehensive school students. In LAINE, Anu, LAVONEN, Jarri, MEISALO, Veijo (eds.). Current Research on Mathematics and Science Education. Research Report 253, Helsinky: University of Helsinky, 2005, pp. 80-102. 


\section{Př́loha 1}

Položky části „Já a výzvy životního prostředí” dotazníku projektu ROSE

1. Ohrožování životního prostředí se mě netýká.

2. Budoucnost světa se jeví pohledem environmentálních problémů bezútěšná a beznadějná.

3. Environmentální problémy jsou zveličovány.

4. Věda a technologie mohou vyřešit všechny environmentální problémy.

5. Jsem ochoten(a) řešit environmentální problémy i za cenu obětování mnohých požitků.

6. Sám mohu ovlivnit to, co se děje s životním prostředím.

7. Klidně můžeme najít řešení našich environmentálních problémů.

8. Lidé se př́liš obávají environmentálních problémů.

9. Environmentální problémy mohou být vyřešeny bez velkých změn $v$ našem způsobu života.

10. Lidé by se měli více starat o ochranu životního prostředí.

11. Za řešení environmentálních problémů světa jsou odpovědné bohaté země.

12. Myslím si, že každý z nás může přispět významným dílem k ochraně životního prostředí.

13. Environmentální problémy by se měly nechat pouze odborníkům.

14. Při pohledu do budoucnosti jsem spíše optimista.

15. Zvířata by měla mít stejné právo na život jako lidé.

16. Je správné využívat pokusná zvířata v lékařských experimentech, pokud se tím dají zachraňovat lidské životy.

17. Téměř všechna lidská činnost je škodlivá pro životní prostředí.

18. Svět př́rody je posvátný a měl by být zachován nedotknutelný. 


\section{Př́loha 2}

Pět nejvíce pozitivně a pět nejvíce negativně hodnocených tvrzení v dotazníku ROSE v části „Já a výzvy životního prostředí" u žáků ZŠ a studentů gymnázia

\begin{tabular}{|l|l|l|}
\hline $\begin{array}{l}\text { (Část D) Já a výzvy životního prostředí } \\
\text { Do jaké míry souhlasíš s následujícími prohlášeními o problémech životního prostředí (o } \\
\text { environmentálních problémech) např. znečištování ovzduší a vody, vyčerpatelnost zdrojů, } \\
\text { globální změny podnebí atd.? }\end{array}$ \\
\hline zš & Souhlasím & Průměr \\
\hline 1. & Lidé by se měli více starat o ochranu životního prostředí & 3,539 \\
\hline 2. & $\begin{array}{l}\text { Myslím si, že každý z nás může přispět významným dílem } \\
\text { k ochraně životního prostředí }\end{array}$ & 3,343 \\
\hline 3. & Zvířata by měla mít stejné právo na život jako lidé & 3,205 \\
\hline 4. & Svět př́rody je posvátný a měl by být zachován nedotknutelný & 2,841 \\
\hline 5. & Klidně můžeme najít řešení našich environmentálních problémů & 2,692 \\
\hline GYM & Souhlasím & Průměr \\
\hline 1. & Lidé by se měli více starat o ochranu životního prostředí & 3,614 \\
\hline 2. & $\begin{array}{l}\text { Myslím si, že každý z nás může přispět významným dílem } \\
\text { k ochraně životního prostředí }\end{array}$ & 3,262 \\
\hline 3. & Zviřata by měla mít stejné právo na život jako lidé & 3,157 \\
\hline 4. & Svět př́rody je posvátný a měl by být zachován nedotknutelný & 2,738 \\
\hline 5. & Klidně mǔžeme najít řešení našich environmentálních problémů & 2,716 \\
\hline zš & Nesouhlasím & Průměr \\
\hline 1. & Ohrožování životního prostředí se mě netýká & 1,873 \\
\hline 2. & $\begin{array}{l}\text { Environmentální problémy mohou být vyřešeny bez velkých změnn } \\
\text { v našem způsobu života }\end{array}$ & 2,064 \\
\hline 3. & Environmentální problémy by se měly nechat pouze odborníkům & 2,070 \\
\hline 4. & Environmentální problémy jsou zveličovány & 2,144 \\
\hline 5. & $\begin{array}{l}\text { Jsem ochoten(a) řešit environmentální problémy i za cenu } \\
\text { obětování svých mnohých požitků a výhod }\end{array}$ & 2,228 \\
\hline GYM & Nesouhlasím & Průměr \\
\hline 1. & Ohrožování životního prostředí se mě netýká & 1,667 \\
\hline 2. & Environmentální problémy by se měly nechat pouze odborníkům & 1,824 \\
\hline 3. & $\begin{array}{l}\text { Environmentální problémy mohou být vyřešeny bez velkých změn } \\
\text { v našem způsobu života }\end{array}$ & 1,942 \\
\hline 4. & Environmentální problémy jsou zveličovány & 2,054 \\
\hline 5. & Téměř všechna lidská činnost je škodlivá pro životní prostředí & 2,114 \\
\hline
\end{tabular}


Časopis Envigogika vydává Centrum pro otázky životního prostředí UK. Vývoj časopisu je podpořen projektem OP VK Mezioborová sít udržitelného rozvoje.

Více najdete na internetových stránkách projektu mosur.czp.cuni.cz
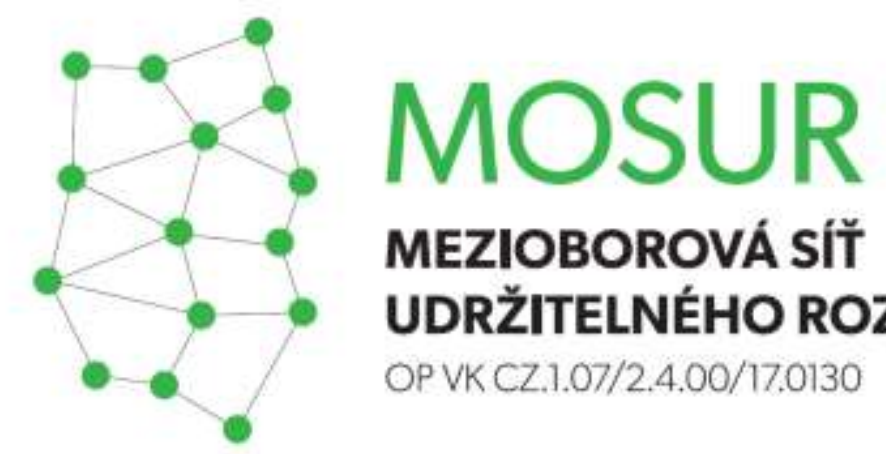

\section{MEZIOBOROVÁ SÍT} UDRŽITELNÉHO ROZVOJE

OP VK CZ.1.07/2.4.00/17.0130
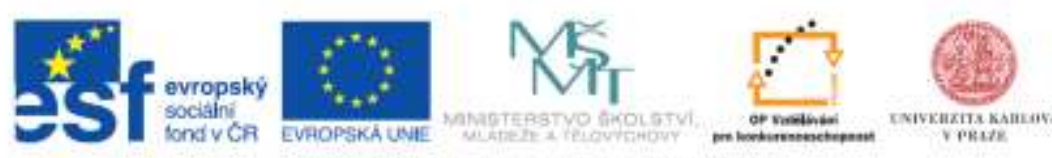

INVESTICE DO ROZVOJE VZDELAVANI 